\title{
Application of biological activator in Urochloa decumbens submitted to single and in consortium cultivation
}

\author{
Aplicação de ativador biológico em Urochloa decumbens submetido a cultivo único e em consórcio \\ Aplicación de activador biológico en Urochloa decumbens sometido a cultivo individual y en \\ consorcio
}

Dthenifer Santana Cordeiro

ORCID: https://orcid.org/ 0000-0001-7611-6040 Universidade Estadual de Mato Grosso do Sul, Brazil E-mail: dthennyfer.santana@hotmail.com

Douglas Schlosser Machado

ORCID: https://orcid.org/ 0000-0002-4973-3008 Universidade Estadual de Mato Grosso do Sul, Brazil E-mail: douglas77213@gmail.com

Francisco Eduardo Torres

ORCID: https://orcid.org/0000-0002-6114-0096 Universidade Estadual de Mato Grosso do Sul, Brazil E-mail: feduardo@uems.br

Angelita dos Santos Zanuncio

ORCID: https://orcid.org/ 0000-0002-7191-8498 Universidade Estadual de Mato Grosso do Sul, Brazil E-mail: angelitazanuncio@gmail.com

Gabriele Gonçalves de Mendonça

ORCID: https://orcid.org/0000-0001-5659-4109 Universidade Estadual de Mato Grosso do Sul, Brazil E-mail: gabriele.goncalves@outlook.com

Elen Regina Cáceres de Souza

ORCID: https://orcid.org/ 0000-0003-4854-3808 Universidade Estadual de Mato Grosso do Sul, Brazil E-mail: elen.caceres@hotmail.com

Gustavo Ruivo Salmazzo

ORCID: https://orcid.org/ 0000-0002-7686-699X Universidade Estadual de Mato Grosso do Sul, Brazil

E-mail: gustavo_ruivosalmazzo@hotmail.com

\begin{abstract}
Low pasture production is due to degradation that leads to soil erosion processes. These conditions decrease the production of forage biomass and its resistance to drought. Thus, this study aimed to evaluate the viability of $U$. decumbens and millet consortium and in single cultivation, related to bromatological quality, using biological activator. The study was carried out in the field located in the experimental area of the Universidade Estadual de Mato Grosso do Sul - Unidade Universitária de Aquidauana (UEMS / UUA), phytotechnics sector, located in the city of Aquidauana MS, region of the Pantanal ecotone. It was adopted a randomized blocks in subdivided plots experimental design with 4 replications, treatments classified in: T1: Millet + activator, T2: Millet, T3: 75\% Millet and 25\% U. decumbens + activator, T4: 75\% Millet and 25\% U. decumbens, T5: U. decumbens + activator, T6: U. decumbens, T7: 25\% Millet and 75\% U. decumbens + activator, T8: 25\% Millet and 75\% U. decumbens, T9: 50\% Millet and 50\% U. decumbens + activator, T10: 50\% Millet and 50\% U. decumbens. At 70 DAE samples consisting of 60 leaves per plot were collected in each treatment. The collected part was the flag leaf, eliminating the basal third portion, apical and the midrib of each leaf. Then the analyzes of dry matter, ashes, PB, FDN and FDA were performed. The treatments that presented the best nutritional values were $\mathrm{T} 3$ and $\mathrm{T} 4$, however, analyzing grazing efficiency, it is recommended the treatments $\mathrm{T} 7$ and $\mathrm{T} 8$, once that they showed similar quality and they would be better used by the animals.
\end{abstract}

Keywords: Urochloa decumbens; Pennisetum glaucum; Consortium; Crude protein.

\section{Resumo}

A baixa produção de pastagens ocorre devido à degradação que leva a processos de erosão do solo. Essas condições diminuem a produção de biomassa forrageira e sua resistência à seca. Assim, este estudo teve como objetivo avaliar a viabilidade de U. decumbens e consórcio milheto e em cultivo único, quanto à qualidade bromatológica, utilizando 
ativador biológico. O estudo foi realizado em campo localizado na área experimental da Universidade Estadual de Mato Grosso do Sul - Unidade Universitária de Aquidauana (UEMS / UUA), setor de fitotecnia, localizada no município de Aquidauana MS, região do ecótono Pantanal. Adotou-se o delineamento experimental em blocos ao acaso em parcelas subdivididas com 4 repetições, os tratamentos classificados em: T1: Millet + ativador, T2: Millet, T3: 75\% Millet e 25\% U. decumbens + ativador, T4: 75\% Millet e $25 \%$ U. decumbens, T5: U. decumbens + ativador, T6: U. decumbens, T7: 25\% Millet e 75\% U. decumbens + ativador, T8: 25\% Millet e 75\% U. decumbens, T9: 50\% Millet e 50\% U. decumbens + ativador, T10: 50\% Millet e 50\% U. decumbens. Aos 70 DAE, foram coletadas amostras de 60 folhas por parcela em cada tratamento. A parte coletada foi a folha bandeira, eliminando o terço basal, apical e a nervura central de cada folha. Em seguida, foram realizadas as análises de matéria seca, cinzas, PB, FDN e FDA. Os tratamentos que apresentaram os melhores valores nutricionais foram T3 e T4, porém, analisando a eficiência de pastejo, recomenda-se os tratamentos T7 e T8, uma vez que apresentaram qualidade semelhante e seriam mais bem utilizados pelos animais.

Palavras-chave: Urochloa decumbens; Pennisetum glaucum; Consórcio; Proteína bruta.

\section{Resumen}

La baja producción de pastos se debe a la degradación que conduce a procesos de erosión del suelo. Estas condiciones disminuyen la producción de biomasa forrajera y su resistencia a la sequía. Así, este estudio tuvo como objetivo evaluar la viabilidad de U. decumbens y consorcio de mijo y en un solo cultivo, relacionada con la calidad bromatológica, utilizando activador biológico. El estudio se realizó en el campo ubicado en el área experimental de la Universidad Estatal de Mato Grosso do Sul - Unidad Universitaria de Aquidauana (UEMS / UUA), sector de fitotecnia, ubicada en la ciudad de Aquidauana MS, región del ecotono Pantanal. Se adoptó un diseño experimental de bloques al azar en parcelas subdivididas con 4 repeticiones, tratamientos clasificados en: T1: Mijo + activador, T2: Mijo, T3: 75\% Mijo y 25\% U. decumbens + activador, T4: 75\% Mijo y $25 \%$ U. decumbens, T5: U. decumbens + activador, T6: U. decumbens, T7: $25 \%$ Mijo y 75\% U. decumbens + activador, T8: $25 \%$ Mijo y $75 \%$ U. decumbens, T9: 50\% Mijo y 50\% U. decumbens + activador, T10: 50\% Mijo y 50\% U. decumbens. A los 70 DDE se recolectaron muestras de 60 hojas por parcela en cada tratamiento. La parte recolectada fue la hoja bandera, eliminando la tercera porción basal, apical y nervadura central de cada hoja. Luego se realizaron los análisis de materia seca, cenizas, PB, FDN y FDA. Los tratamientos que presentaron mejores valores nutricionales fueron T3 y T4, sin embargo, analizando la eficiencia del pastoreo, se recomienda los tratamientos $\mathrm{T} 7$ y $\mathrm{T} 8$, una vez que mostraron calidad similar y serían mejor aprovechados por los animales.

Palabras clave: Urochloa decumbens; Pennisetum glaucum; Consorcio; Proteína cruda.

\section{Introduction}

Although the national livestock has had a reduced productivity, it is still expressive, because part of this low production is due to the degradation of the pasture, which leads to erosive processes of the soil. These conditions decrease the production of forage biomass and its resistance to drought (Veloso, et al., 2020).

Urochloa decumbens is one of the species used in brazilian's pastures, mainly in the central west, This forage grass is originally from Africa and it was introduced in Brazil around 1960, widely used in livestock systems, occupying 80\% of brazilian pasture areas, due to its rusticity, low demands on fertility and easy handling (Embrapa, 2013).

However, U. decumbens has some disadvantageous characteristics when it's compared to other species, such as a nutritional value below the average of current forages, crude protein (PB) ranging from 5.5\% to 8\%, FDN and FDA around $65 \%$ and $30 \%$ respectively, factors that end up compromising the weight gain of the animals submitted to this forage plant (Pariz et al., 2010).

Para Gomes (2011), affirms that the consortium with other crops is a technique that aims to improve general quality of the pasture, thus, the idea of introducing millet (Pennisetum glaucum L.) to this system comes up. It aims to add characteristics of interest of both plants, which aims to result in a pasture that presents higher protein content and more balanced and fertile soil.

P. glaucum is an annual summer grass which requires about $45 \%$ of base saturation of soil, its growth habit is erect with excellent regrowth after grazing, 1.5 to 3 meters height, around $20 \%$ PB content in the leaves, neutral detergent fiber (FDN) and acid detergent fiber (FDA) around $60 \%$ and $30 \%$, respectively, pre and post grazing height of $50 \mathrm{~cm}$ and $20 \mathrm{~cm}$, to maintain consortium system (Embrapa, 2008). 
Therefore, it is notable that millet has a high nutritional value, however, another important factor that explains the expansion of the plant's cultivation area is the adaptation to drought and poor soils, sometimes biologically unbalanced, thus being an easily adaptable plant (Pereira Filho, 2016).

Degraded parts of soil in livestock areas is a common scenario, as a result of inadequate management, where it is biologically, chemically and physically unbalanced. Thus, the application of biological activator is a management alternative, once that the product aims to balance these factors over time (Santana, 2018).

The evaluation of the effect of biological activator on forage plants, single or consortium cultivation, can be an alternative to improve production in the cerrado region. Thus, this study aimed to evaluate the viability of the consortium of $U$. decumbens and millet, and in single cultivation, regarding bromatological quality, using biological activator.

\section{Methodology}

The study was carried out in the field located in the experimental area of the Universidade Estadual de Mato Grosso do Sul - Unidade Universitária de Aquidauana (UEMS / UUA), phytotechnics sector, located in the city of Aquidauana MS, region of the Pantanal ecotone covering the geographical coordinates $20^{\circ} 27^{\prime} 12^{\prime}$ ' $\mathrm{S}$ and $55^{\circ} 40^{\prime} 23^{\prime \prime} \mathrm{W}$, and average altitude of $170 \mathrm{~m}$.

The region climate classification, according to Köppen-Geiger, is Aw (Tropical Savanna) type, average annual rainfall of $1200 \mathrm{~mm}$ and average, maximum and minimum temperatures of 33 and $19^{\circ} \mathrm{C}$, respectively. The range temperature variation while the project was going on in the field was about $20^{\circ} \mathrm{C}$ and $27^{\circ} \mathrm{C}$. Rainfall in the months of January $(400 \mathrm{~mm})$, February (150 mm), March (70 mm), April (20-30 mm), May and June had no significant rainfall.

The soil in the study area was classified by Embrapa (2010), as a red-yellow dystrophic Argisol presenting sandy texture, according to Embrapa's criteria (2), and following characteristics in the 0 - $0.20 \mathrm{~m}$ layer: $\mathrm{pH}$ (H2O) 6 ,2; Exchangeable $\mathrm{Al}$ (cmolc dm-3) 0,0; $\mathrm{Ca}+\mathrm{Mg}$ (cmolc dm-3) 4,31; P (mg dm-3) 41,3; K (cmolc dm-3) 0,2; Organic matter (g dm-3) 19,74; V (\%) 45; m (\%) 0,0; Sum of bases (cmolc dm-3) 2,3; CTC (cmolc dm-3) 5,1.

It was adopted a randomized blocks in subdivided plots experimental design with 4 replications, treatments classified in: T1: Millet + activator, T2: Millet, T3: 75\% Millet and 25\% U. decumbens + activator, T4: $75 \%$ Millet and $25 \% \mathrm{U}$. decumbens, T5: U. decumbens + activator, T6: U. decumbens, T7: 25\% Millet and 75\% U. decumbens + activator, T8: 25\% Millet and 75\% U. decumbens, T9: 50\% Millet and 50\% U. decumbens + activator, T10: 50\% Millet and 50\% U. decumbens.

Firstly, the soil preparation was realized requiring the use of two passages of the plow harrow, operations that were carried out while the soil presented point of friable humidity, guaranteeing efficiency and quality. The plots dimensions were 3,5 X 5 meters, of so that total area of the project was 14 X 50 meters, totaling $700 \mathrm{~m} 2$. Then the planting furrow was opened.

As for sowing, millet and U. decumbens seeds were weighed and mixed according to the proportion of plants in each plot, in which the total seed mass was 75 grams per plot; the seeds were processed with $100 \mathrm{~mL}$ of pc ha-1 of Standak top ${ }^{\circledR}$ fungicide.

Sowing was done manually, in $50 \mathrm{~cm}$ spaced rows, in which the seeds were about $3-4 \mathrm{~cm}$ deep and at 15 days manual thinning was performed in order to adjust precisely the proportion of plants of each species in each treatment.

The applications of the biological activator were realized at 15 and 25 days after emergence (DAE), next to the plant lap and using a costal sprayer, in day hours of little wind and mild temperature.

At 20 DAE, it was performed manual clear off in the space between the lines, aiming to remove existing weeds and manual picking in the sowing row, to make sure that there was no problem due to competition between the crops and the weeds. The bank of weed species was composed mainly of trapoeraba (Commelina benghalensis L), tiririca (Cyperus rotundus L.), picão preto (Bidens pilosa) and carrapicho grass (Cenchrus echinatus). 
An insecticide was applied $25 \mathrm{DAE}$, aiming to control the Grass culm borer (Diatraea saccharalis). The commercial product name is "Engeo Pleno S" and dosage was $200 \mathrm{~mL}$ ha-1; it was applied with a spray, volume of $350 \mathrm{~L}$ ha-1.

Around 45 DAE it was observed the incidence of blast in millet, a disease caused by the fungus Pyricularia grisea. It is leaf spot that ends up coalescing as the days passing by, occupying a significant part of the leaf area, once that there was no leaf application of fungicide.

At 70 DAE samples consisting of 60 leaves per plot were collected in each treatment. The collected part was the flag leaf, eliminating the basal third portion, apical and the midrib of each leaf. Then the analyzes of dry matter, ashes, PB, FDN and FDA were performed, as described below.

In the determination of dry matter, the plant material was dried in a forced air circulation oven, at $65{ }^{\circ} \mathrm{C}$ for 72 hours. After this period, the samples were weighed to obtain ASA (air-dried sample) and grinded in a Willey mill, and then processed, packaged and labeled. For this determination, $2 \mathrm{~g}$ of air-dried sample (ASA) were added to previously weighed and dried crucibles, which remained $24 \mathrm{~h}$ at $105^{\circ}$ in a sterilization oven. After this, they were taken to desiccators and finally weighed to obtain DM.

To ashes analyze, the crucibles that came from the determination of DM, were taken to a muffle furnace, where they remained for $4 \mathrm{~h}$ in a temperature of $600^{\circ} \mathrm{C}$. After this, they were cooled in a desiccator, until reach room temperature and then weighed to obtain ashes results.

Crude protein (PB) values were obtained after analyze following the methodology proposed by Detmann et al. 2012, according to the publication "Methods for food analysis". For PB analysis, it was followed the method proposed by Kjehdahl, where $0,25 \mathrm{~g}$ of the air-dried sample was weighed on an analytical balance.

To obtain insoluble fibers in neutral and acid detergent values, the methodology proposed by Van Soest (1967), was used. The packages that were used in the analyses were made with non-woven fabric (TNT $100 \mathrm{~g} / \mathrm{m} 2$ ), it was cleaned several times using neutral commercial detergent, washed in boiling water, distilled water and acetone, aiming total removal of residues.

The packages were dried in a forced ventilated oven for 24 hours in a temperature of $60^{\circ} \mathrm{C}$. So, they were taken to the desiccator until reach thermic balance, and then, they were weighed. Afterwards, the equivalent of $20 \mathrm{mg}$ of vegetable sample per $\mathrm{cm} 2$ was added to the package.

The bags were packed in a plastic container where the neutral detergent was added $(100 \mathrm{~mL}$ of solution for each gram of sample), immediately afterwards they were taken to an autoclave for one hour at $105^{\circ} \mathrm{C}$. At the end of the process, the packages were washed with hot distilled water and acetone to remove the detergent solution.

The material was dried in a ventilated oven for 24 hours at $60^{\circ} \mathrm{C}$ and then it was conducted to an unventilated oven for 2 hours at $105^{\circ} \mathrm{C}$, stored in a desiccator and carefully weighed.

Right after this, the acid detergent solution was added in the same solution/sample ratio as the neutral detergent, and the sequence of steps is identical to the ones followed to FDN obtention. As soon as this process was over, the bags containing the samples were weighed and the fraction of insoluble fibers in acid detergent was obtained.

The data were collected and evaluated by analysis of variance (ANAVA), the means were compared by the Tukey test at $5 \%$ probability and the main components analysis was performed.

\section{Results and Discussion}

The results obtained were evaluated through analysis of variance of the analyzed variables considering as source of variation: block, forage, activator and interactions among them (Table 1). 
Table 1. $\mathrm{P}$-values of the analysis of variance for the variables: crude protein (PB), fibers in neutral detergent (FDN), fibers in acid detergent (FDA), dry matter (MS) and ash (ASHES), evaluated in different \% of $U$. decumbens + Millet with or without the use of Microgreo ${ }^{\circledR}$.

\begin{tabular}{llllll}
\hline FV & PB & FDN & FDA & MS & CINZAS \\
\hline & \multicolumn{5}{c}{$\%$} \\
\hline Blocks & 0,99 & 0,60 & 0,64 & 0,06 & 0,23 \\
Forage & 0,16 & 0,71 & 0,80 & 0,32 & $0,00^{*}$ \\
Activator & 0,15 & 0,24 & $0,04^{*}$ & 0,07 & 0,13 \\
P X AT & 0,69 & 0,68 & 0,74 & 0,20 & 0,36 \\
CV 1 & 10,93 & 7,22 & 9,59 & 0,57 & 5,50 \\
CV 2 & 4,24 & 3,79 & 2,93 & 0,27 & 5,34 \\
Mean & 10,59 & 54,41 & 27,15 & 90,93 & 10,80
\end{tabular}

FORAGE = population; ACTIVATOR = solution; $\mathrm{P}$ X AT $=$ Forage interaction with activator CV1 = plot variation coefficient $\mathrm{CV} 2=$ coefficient of variation of the subplot. Source: Authors.

It is noted that there was no significant difference between the interaction of the sources of variation. However, when they were analyzed separately, there was significance for the ash variable of the forage. Regarding to the activator FDA, it showed a significant difference in the treatment with the activator. Trindade et al. (2017) evaluating the use of the activator in Urochloa Brizantha cv. BRS Marandu found out similar results, in which the use of this product showed no significant difference for the levels of DM and FDN.

The Table 2 shows that there was no significance for the Tukey test, at 5\% probability, for most of the analyzed variables regarding to the variation of different percentages of millet and $U$. decumbens. The statistical difference is for the ash variable only, so as much higher the percentage of millet in the treatments, the values observed in ash increase too.

Table 2. Percentages of crude protein (PB), fiber in neutral detergent (FDN), fiber in acid detergent (FDA), dry matter (MS) and ash (ASHES) evaluated in different $\%$ of millet $+U$. decumbens.

\begin{tabular}{cccccl}
\hline FORRAGEM & PB & FDN & FDA & MS & CINZAS \\
\hline Milheto & $11,21 \mathrm{a}$ & $53,04 \mathrm{a}$ & $26,39 \mathrm{a}$ & $91,25 \mathrm{a}$ & $12,11 \mathrm{a}$ \\
$75 \% \mathrm{M}+25 \% \mathrm{U}$ & $11,17 \mathrm{a}$ & $53,59 \mathrm{a}$ & $26,75 \mathrm{a}$ & $90,88 \mathrm{a}$ & $11,65 \mathrm{ab}$ \\
$50 \% \mathrm{M}+50 \% \mathrm{U}$ & $10,08 \mathrm{a}$ & $55,13 \mathrm{a}$ & $27,91 \mathrm{a}$ & $90,75 \mathrm{a}$ & $11,13 \mathrm{bc}$ \\
$25 \% \mathrm{M}+75 \% \mathrm{U}$ & $10,50 \mathrm{a}$ & $55,21 \mathrm{a}$ & $27,37 \mathrm{a}$ & $90,75 \mathrm{a}$ & $10,49 \mathrm{c}$ \\
Urochloa & $10,00 \mathrm{a}$ & $55,10 \mathrm{a}$ & $27,32 \mathrm{a}$ & $91,00 \mathrm{a}$ & $8,63 \mathrm{~d}$ \\
\hline
\end{tabular}

Same letters in the same column do not differ from the Tukey test at 5\% probability. M = Millet, U = Urochloa decumbens. Source: Authors.

The ash analysis represents the inorganic matter remaining in the sample after being incinerated, providing prior information about nutritional value of the forage. Thus, as much higher the ash content of a certain forage, the greater amount of nutrients it contains (Menezes \& Purgatto, 2016).

As it was observed in the analyzes realized on this work, T1, T2, T3 and T4 treatments showed the highest ash values, and it is possible to affirm that they have the highest nutritional value. Guimarães Júnior (2006) described that millet has high ash contents, even when it is compared to crops such as sorghum. 
Analyzing the data on this research it is possible to observe that the consortium of millet with $U$. decumbens increases ash content. Pinho et al. (2013) found out ash contents for millet around 14\%, whereas Santos et al. (2004) showed ash values for $U$. decumbens around 7.5\%. Considering these results and comparing to the provisions presented by Santos et al. (2004), the highest levels of ashes from $U$. decumbens in this study are attributed to the conditions of the consortium with millet.

There was also no statistical difference between treatments for NDF and FDA, however, the levels obtained were lower than those found out in the literature. It can be attributed to the soil fertility of study field, which is high, when compared to other situations in conventional grazing areas. Costa et al. (2010) observed that for U. brizantha cv. Marandu as much higher the nitrogen content applied is, the lower the levels of NDF and FDA.

In a study, Pariz et al. (2010) found out values around 70\% and 50\% for FDN and FDA in millet, respectively. Frota et al. (2015) presented values slightly higher than those found in this work, about 57\% and 35\% for FDN and FDA for millet, respectively. Santos et al. (2004) showed values of $64 \%$ and $29 \%$ for FDN and FDA for $U$. decumbens.

The DM levels did not show statistical difference. Similar results were observed by Trindade et al. (2017), where the DM content was around $90 \%$ for $U$. brizantha cv. BRS Marandu.

In Table 3, it can be seen that there was no significance for most of the variables analyzed regarding the absence or presence of the activator. The statistical difference was observed only for the FDA variable, the presence of the product provides an increase in this value, representing a decrease in the bromatological value, once that as much higher FDA content, the lower the bromatological quality of the forage.

Table 3. Percentages of crude protein (PB), fiber in neutral detergent (FDN), fiber in acid detergent (FDA), dry matter (MS) and ash (ASHES) evaluated with or without the use of biological fertilizer.

\begin{tabular}{llllll}
\hline ATIVADOR & PB & FDN & FDA & MS & CINZAS \\
\hline \multicolumn{7}{c}{$\%$} & & \\
\hline ABSENCE & $10,70 \mathrm{a}$ & $54,01 \mathrm{a}$ & $26,84 \mathrm{~b}$ & $90,85 \mathrm{a}$ & $10,65 \mathrm{a}$ \\
PRESENCE & $10,49 \mathrm{a}$ & $54,82 \mathrm{a}$ & $27,81 \mathrm{a}$ & $91,00 \mathrm{a}$ & $10,95 \mathrm{a}$ \\
\hline
\end{tabular}

Same letters in the same column are not significant to the Tukey test at $5 \%$ probability. Source: Authors.

The place conditions where the experiment was conducted may have influenced the absence of significant differences for the use of the activator. It has been cultivated under rotational system of oil crops, grasses and green fertilizers for many years, conditioning biologically and chemically the soil of the place.

However, it is considered that the continuous use of biological activators over the years could indeed provide even more favorable conditions, enabling greater root exploration, availability of nutrients and biological balance (Pedó et al., 2016).

There was statistical difference $(\mathrm{p}<0.05)$ for the FDA values; in treatments without biological activator, FDA values were lower than in treatments with activator. FDN and FDA values corresponding to cellulose, lignin, protein damaged by the heat and minerals content in the sample.

\section{Principal component analysis (PCA)}

Principal component analysis (PCA) is performed to assess the influence between variables and procedures. It is a multivariate statistics technique that changes a set of variables into another set of variables of the same dimension, it's known 
as principal components. For Regazzi (2000), in a wide range of PCA utilities, it is recognized the one that accumulates 70\% or more of proportion. It is noted (Table 4) that the accumulation in the second main component was $76.23 \%$.

Table 4. Correlation between bromatological analyzes of different forages and main components.

\begin{tabular}{ccc}
\hline Variables & CP1 & CP2 \\
\hline PB & 0.303 & 0.651 \\
FDN & 0.579 & 0 \\
FDA & 0.556 & 0 \\
ASE & -0.288 & 0.677 \\
MM & -0.426 & 0.222 \\
Accumulated variance & 0.500863 & 0.762287
\end{tabular}

The variables FDN and FDA were the ones that most contributed to the variance of the main component 1 and the variables PB and ASE had the greatest contribution to the main component 2. Source: Authors.

Figure 1 shows positive correlations of treatments located on the right side (T7, T9 and T10) and that they are positively related to the FDA variable, but negatively related to the FDN variable. The treatments T8, T6 and T5 are negatively correlated with FDN. The T4 and T3 treatments are the ones on the left side of the biplot, negatively correlated and influenced for the MM variable. The T1 treatment is also found on the left side of the graph with proximity to ASE. T2 was negatively correlated as well, but far from the analyzed variables.

Figure 1. Biplot of variables projections in the first two main components of the analyzed variables of ten treatments.

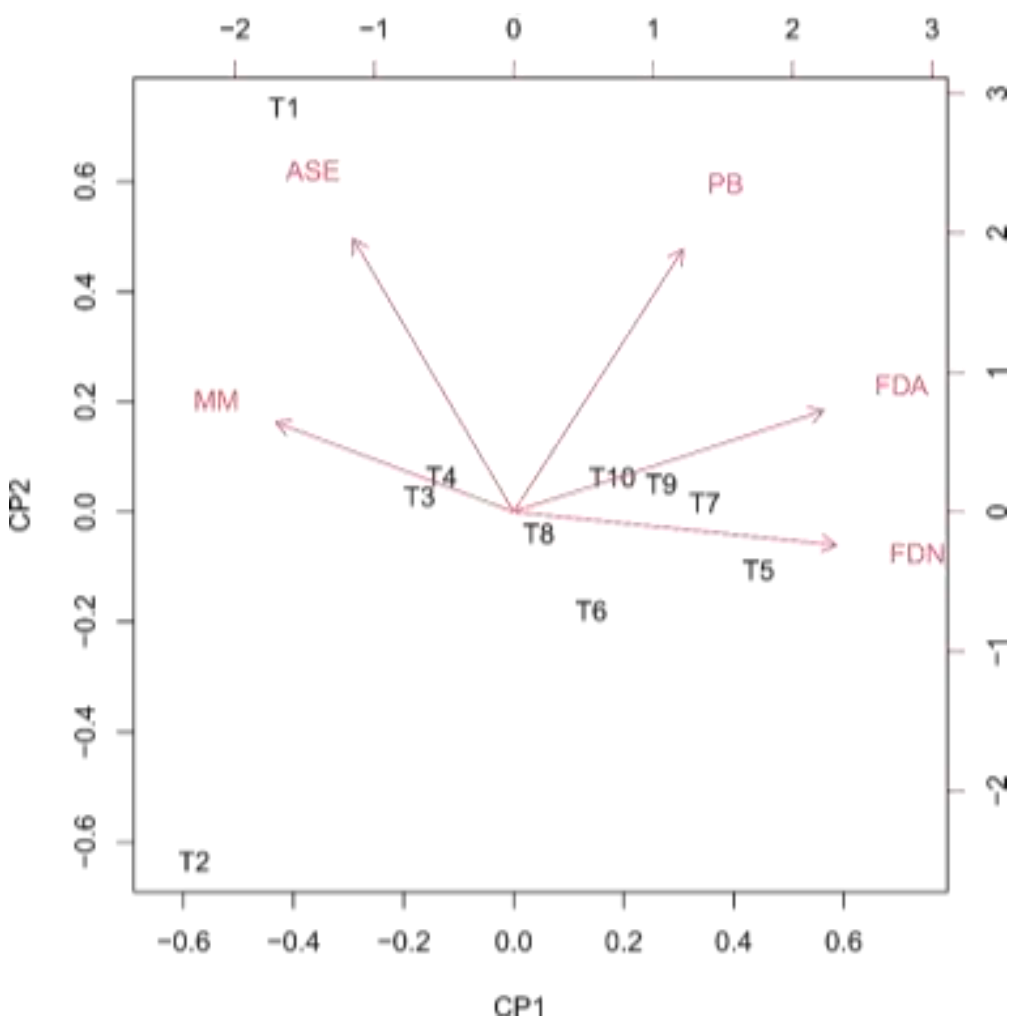

T7, T9 and T10 treatments presented strong connection with FDA, as well as T5, T6 and T8 treatments that showed strong correlation with FDN. It's known that such characteristics are undesirable for a quality forage because the fibers are one of the indigestible fractions to the rumen microbial fermentation (Raffrenato, et. al., 2019). Source: Authors. 


\section{Conclusion}

Alluding to the mentioned facts above, it is possible to conclude that the consortium of $U$. decumbens with millet for direct grazing of beef cattle is a viable alternative, once that the consortium raises the bromatological quality of the forage, ensuring greater weight gain of the animals and the use of biological activator in a single year did not show significant results for the performed analyzes.

The treatments that presented better nutritional values were T3 and T4. However, analyzing grazing efficiency, it is recommended the treatments $\mathrm{T} 7$ and $\mathrm{T} 8$, once that they showed similar quality and they would be better used by the animals.

\section{References}

Alvarenga, R. C., Novotny, E. H., Pereira-Filho, I. A., Santana, D. P., Pereira, F. T. F., Hernani, L. C., \& Cruz, J. C. C. (2010). Cultivo do milho. Sete Lagoas: Embrapa Milho e Sorgo.

Costa, T. V. D. A. M. (2009). Agripec: um modelo para estimar custos economicos e emissões de gases efeito-estufa para a pecuaria bovina brasileira.

Cerrados, E. (2017). Análise Temporal de Variáveis Climáticas Monitoradas entre 1974 e 2013 na Estação Principal da Embrapa Cerrados.

de Castro Tobaruela, E. (2016). Avaliação do conteúdo de carboidratos de frutas cultivadas em diferentes regiões do Brasil (Doctoral dissertation, Universidade de São Paulo).

Fernandes, F. T., \& Oliveira, E. D. (2000). Principais doenças na cultura do milho. Embrapa-CNPMS. Circular técnica.

Ferreira, F. N., Oliveira, I. C. M., de Andrade, C. D. L. T., Simeão, R. M., \& de Souza, I. R. P. (2020). Produção de Silagem de Milheto sob Diferentes Lâminas de Irrigação. Embrapa Milho e Sorgo-Boletim de Pesquisa e Desenvolvimento (INFOTECA-E).

Frota, B. C. B., de Assis Pires, D. A., De Aguilar, P. B., Rodrigues, J. A. A. S., Júnior, V. R. R., \& dos Reis, S. T. Características nutricionais de genótipos de milheto no período da safra. Scientia Agraria Paranaensis, 14(2), 106-111.

Monteiro, R., Behling, M., Tonini, H., Lulu, J., Coletti, A., \& Shiratsuchi, L. (2016). Integração entre a Lavoura, a Pecuária e a Floresta: ciência e arte. In Embrapa Agrossilvipastoril-Artigo em anais de congresso (ALICE). In: Simpósio Brasileirode Agropecuária Sustentável., 8.; International Conference On Sustainable Agriculture, 5., 2016. Sinop. Ciência, tecnologia e inovação para o desenvolvimento sustentável das novas fronteiras agrícolas: anais. Sinop. 123140. SIMBRAS..

Rodrigues, T. C. G. D. C. (2015). Comportamento Ingestivo E Metabólitos Sanguíneo Em Cordeiros Submetidos A Dietas Com Silagem De Milheto Amonizada.

Kluthcouski, J., Cordeiro, L. A. M., Ceccon, G., \& Oliveira, P. D. (2013). Braquiária na agropecuária brasileira: uma história de sucesso. Embrapa Agropecuária Oeste-Capítulo em livro técnico (INFOTECA-E).

Pariz, C. M., Andreotti, M., Azenha, M. V., Bergamaschine, A. F., de Mello, L. M. M., \& Lima, R. C. (2010). Massa seca e composição bromatológica de quatro espécies de braquiárias semeadas na linha ou a lanço, em consórcio com milho no sistema plantio direto na palha. Acta Scientiarum. Animal Sciences, 32(2), 147-154.

Pinheiro, R. C. (2018). Produtividade De Milho Em Plantio Direto Com Diferentes Doses De Adubação Química Associado À Adubação Biológica.

Pinho, R. M. A., Santos, E. M., Rodrigues, J. A. S., Macedo, C. H. O., Campos, F. S., Ramos, J. P. D. F., \& Perazzo, A. F. (2013). Avaliação de genótipos de milheto para silagem no semiárido. Revista Brasileira de Saúde e Produção Animal, 14(3), 426-436.

Raffrenato, E., Nicholson, C. F., \& Van Amburgh, M. E. (2019). Development of a mathematical model to predict pool sizes and rates of digestion of 2 pools of digestible neutral detergent fiber and an undigested neutral detergent fiber fraction within various forages. Journal of dairy science, 102 (1), $351-364$.

Regazzi, A. J. (2000). Análise multivariada, notas de aula INF 766. Departamento de Informática da Universidade Federal de Viçosa, 2.

Santos, E. D. G., Paulino, M. F., Queiroz, D. S., Valadares Filho, S. D. C., Fonseca, D. M. D., \& Lana, R. D. P. (2003). Avaliação de pastagem diferida de Brachiaria decumbens Stapf: 1. Características químico-bromatológicas da forragem durante a seca.

Van Soest, P. J. (1967). Development of a comprehensive system of feed analyses and its application to forages. Journal of animal Science, 26(1), 119-128.

Veloso, G. A., Ferreira, M. E., Júnior, L. G. F., \& da Silva, B. B. (2020). Modelling gross primary productivity in tropical savanna pasturelands for livestock intensification in Brazil. Remote Sensing Applications: Society And Environment, 17, 100288. 